\title{
Botanic Garden Profile: The National Botanic Garden of Wales at 20
}

\section{Will Ritchie ${ }^{1}$}

\section{Abstract}

The National Botanic Garden of Wales celebrated its 20th anniversary in 2020 with many achievements and challenges for staff, volunteers and stakeholders to reflect upon. An ambitious project since its inception, the Botanic Garden has grown from humble beginnings into an established national institution in its first two decades, with the tireless efforts of many helping it to flourish. Early proponents of the idea did much to foster others' support, and what started as a vision shared between a small group of enthusiasts became a Millennium Commission funded project in 1996. Since opening to the public in 2000, much work has been done to create the gardens, infrastructure and teams necessary to pursue the Botanic Garden's mission. In a climate of increasing biodiversity loss and environmental degradation, science, horticulture and education programmes have been developed which continue to make tangible contributions to the study, conservation and interpretation of plant diversity in Wales and beyond. With 568 acres (230 ha) to develop further still and world-class facilities such as the Great Glasshouse, the Botanic Garden aims to play an important role in research, conservation, education and public engagement for many years to come.

\section{Introduction}

Located on the first floor of the Science Centre of the National Botanic Garden of Wales (Botanic Garden) is a large room that houses herbarium collections and archives. It is one of the quieter parts of the Botanic Garden and one of my favourite places. I'll often take a peek at the James Cosmo Melvill herbarium collection or at specimens from field trips to Borneo with students from Aberystwyth University. When exploring the archives, I enjoy reading about the early days of the Botanic Garden and how it came to be. It was an incredibly ambitious project, established thanks to the tireless efforts of many. When looking at pictures and accounts of 24 May 2000, the day the Botanic Garden first opened to the public, I feel privileged to be a part of this project and to have inherited others' vision and legacy. For me, the establishment of the Botanic Garden was a statement of intent and identity. For a nation in the earliest years of a new devolution settlement, to create a national institution, dedicated to biodiversity conservation, education and public engagement, was bold and symbolic. The message was clear: Wales aspired to be a modern, environmentally conscious and globally responsible nation. As we celebrated our 20th anniversary last year, many of us took the opportunity to reflect on the challenges and successes of those early years. As a maturing and firmly rooted institution, we are now looking ahead and focusing on playing a positive role in Wales' future.

${ }^{1}$ Will Ritchie is Curator of the National Botanic Garden of Wales.

Address: National Botanic Garden of Wales, Llanarthne, Carmarthenshire, SA32 8HG, Wales, UK.

Email: will.ritchie@gardenofwales.org.uk 


\section{Origins}

Port Talbot's industrial landscape in the depths of winter may be an unusual place for a botanic garden's story to begin. Still, it was the scene for the first encounter between three influential figures in our history. The town, home to one of the largest steelworks in Europe, was the last stop on a train journey west for Professor Ghillean Prance and Edmund de Rothschild, both prominent names in horticulture, in December 1989. The Director at the Royal Botanic Gardens, Kew (Kew) and owner of Exbury Gardens respectively were close acquaintances and had jointly accepted an invitation to Wales based on the prospect of warm hospitality and a new project that would excite the imagination (Prance, 1989a). They were met on the platform by William Wilkins, a Carmarthenshire-based artist of international repute, having exhibited in the renowned galleries of San Francisco, Palm Beach and New York in the years prior. The tours, discussions and exchange of ideas that followed can arguably be regarded as the first step towards a national botanic garden for Wales.

Two years previously, thanks to recommendations from his aunt and a local natural history group, Wilkins started to systematically explore the former Middleton Hall estate, near the village of Llanarthne and not far from his home. Owned by the local authority and divided into tenant farms, the estate was mostly derelict, and little of the Regency-period parkland and water features remained. Enthused by the idea of restoration, Wilkins began to involve others, most notably Dr Andrew Sclater, a garden consultant who would later chair the first steering group. Early discussions with Sclater differed in two regards from a typical restoration of a historic garden (Sclater \&
Clarke, 2000). They were committed to a 'modern role' and new garden of 'botanical calibre' (Wilkins, 1998). The early involvement of Prance and Rothschild was therefore deemed a necessity to meet such aspirations. Wilkins invited Prance and Rothschild to Wales to canvass support for the project. The meeting of minds between an artist, a botanist and a financier was seemingly productive. Their distinct perspectives and aspirations converged, and the idea of a botanic garden at the former Middleton Hall estate was born. The outcome was positive for all parties: Rothschild had previously stated that Wales not having a national botanic garden was 'scandalous'; for Prance it was an opportunity to further the botanic garden network for the common good of plant diversity; and for Wilkins, a new life for the estate was now a possibility (Prance, 1989b).

The 'Kew connection' continued to be instrumental in the early development of the project, with Prance and Rothschild firmly of the mind that Wales needed a national botanic garden, that the estate of Middleton Hall should be its home, and that this was now the time. Michael Maunder, then Head of the Garden Development Unit at Kew, worked as a consultant for the steering group and provided detailed notes on the 'purpose and function of botanic gardens' to ensure all stakeholders were convinced of the merits of a new botanical institution (Maunder, 1990a). All parties were committed to a new role for the former estate. A series of preliminary studies and reports were completed in 1990, including Maunder's 'The National Botanic Garden for Wales: a botanic garden for the 21st century' which summarised the horticultural merits of the project (Maunder, 1990b). Assistance and support from Kew continued throughout the project's developmental stages, helping 


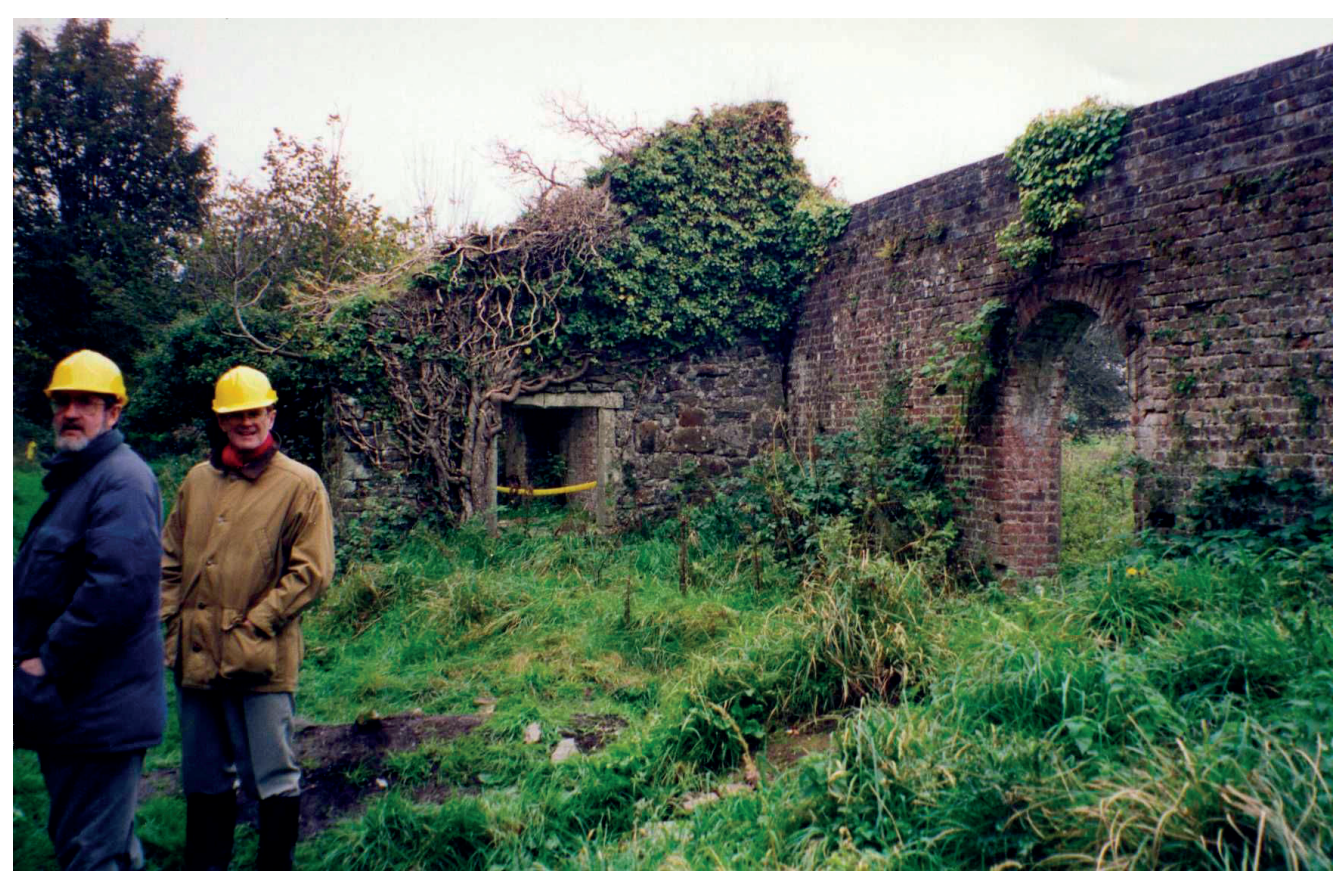

Fig. 1 Former Executive Director Charles Stirton (left) and colleague inspecting the remnants of the Double Walled Garden and Peach House of the former Middleton Hall (Photo: National Botanic Garden of Wales).

to secure Millennium Commission funding in March 1996. Rival bids for a national botanic garden had also been developed in the years leading up to the announcement. Still, the commitment of the steering group, Dyfed County Council and Kew helped the project secure the necessary approvals. Later that year the Botanic Garden's first Executive Director, Professor Charles Stirton, was appointed, arriving from Kew where the project's potential and status was by then well known (Fig. 1). By spring 1997, the turf had been cut, machinery was on site and construction was underway (Sclater \& Clarke, 2000).

\section{Mission and vision}

The Botanic Garden was established as a charity and company limited by guarantee. The objectives and aims of the Botanic Garden were established in the
Memorandum and Articles of Association, first passed on 22 February 1994 (Companies House, 1994). The mission and vision are as follows:
Mission: The Botanic Garden is dedicated to the research and conservation of biodiversity, to sustainability, lifelong learning and the enjoyment of the visitor. Vision: Conservation, Education, Inspiration - playing for Wales on the world stage.

Maunder's notes to the steering group in 1990 included a definition of a botanic garden that helped shape the mission and vision. He defined a botanic garden as 'an ordered and catalogued collection of primarily wild plants used for research, education, conservation, display purposes'. This definition closely resembles the one 
later coined in 1999 for Botanic Garden Conservation International ( $\mathrm{BGCl}$ ) and widely adopted by the botanic garden community today (Wyse Jackson, 1999; Gratzfeld, 2016).

\section{Location and climate}

The Botanic Garden lies 7 miles (11.25 km) south-east of the town of Carmarthen, in the Tywi Valley and Carmarthenshire countryside. The leasehold consists of 568 acres ( $230 \mathrm{ha}$ ) of formal gardens, buildings, woodland, pasture, lakes and meadows. The landscape was much altered during the late 18th and early 19th centuries to reflect the landscape design ideals inspired by William Kent and Lancelot 'Capability' Brown (Bonvoisin, 2016). Much of the parkland's picturesque character, water features and historic pathways have recently been restored as part of a five-year project. Today the estate is the setting for botanical collections, themed gardens, an arboretum and Waun Las National Nature Reserve (NNR) (Fig. 2).

With a temperate oceanic climate and an annual temperature range of 4.6- $-16.1^{\circ} \mathrm{C}$, the conditions are suitable for cultivating a wide range of temperate plants (Climate-Data, 2020). Tropical and Mediterranean climate facilities are also available in the Tropical House and Great Glasshouse respectively. Development of the plant collections is also conditional on the future climate, and planning is focused accordingly. Based on models provided by Forest Research, the Botanic Garden could feasibly provide refuge for plants currently growing in areas such as the northern provinces of Spain, the Dinaric Alps in south and south-east Europe or the Pacific Northwest of North America by 2050 (Broadmeadow et al., 2005). Further parallels are likely for regions of temperate Asia, South America and Australasia.

\section{Garden design}

As early as 1995, architects and landscape architects were enlisted to develop a master plan for the project. In the western portion of the estate, few remnants of prior gardens remained. A deteriorating walled garden, an intact ice house and lakes burdened by years of silt and debris endured. With due diligence to preserving these historical features, a modern garden was designed that integrated them into the plan, blending old with new. Colvin and Moggridge Landscape Architects were tasked with creating pathways, new gardens and a fresh interpretation of a landscape that incorporated the Tywi Valley and surrounding countryside's inherent aesthetic qualities. A central axis was created to guide visitors from the low-lying Gatehouse to the Great Glasshouse - situated on higher ground to the north-east (Sclater $\&$ Clarke, 2000). A procession of visitors on the Broadwalk, enjoying the mixed borders while heading for the Great Glasshouse or restaurant, is now a common sight on busy days. Further auxiliary paths lead to a range of themed gardens. The Japanese, Boulder and Wallace gardens are all common highlights for visitors.

The Great Glasshouse has become a modern icon for Wales (Figs 3 \& 4). The Foster $\&$ Partners-designed building remains one of the largest single-span glasshouses in the world, integrating 24 curved tubular arches and 785 bespoke panes of glass. The dome's structure mirrors the smooth and undulating landscape while acting as a beacon for visitors and locals alike, visible throughout the Botanic Garden and the surrounding area. Gustafson Porter Landscape Architecture designed the interior. The hard landscaping aimed to replicate the substrates and conditions typical of Mediterranean climate regions. White sandstone was used to create a 


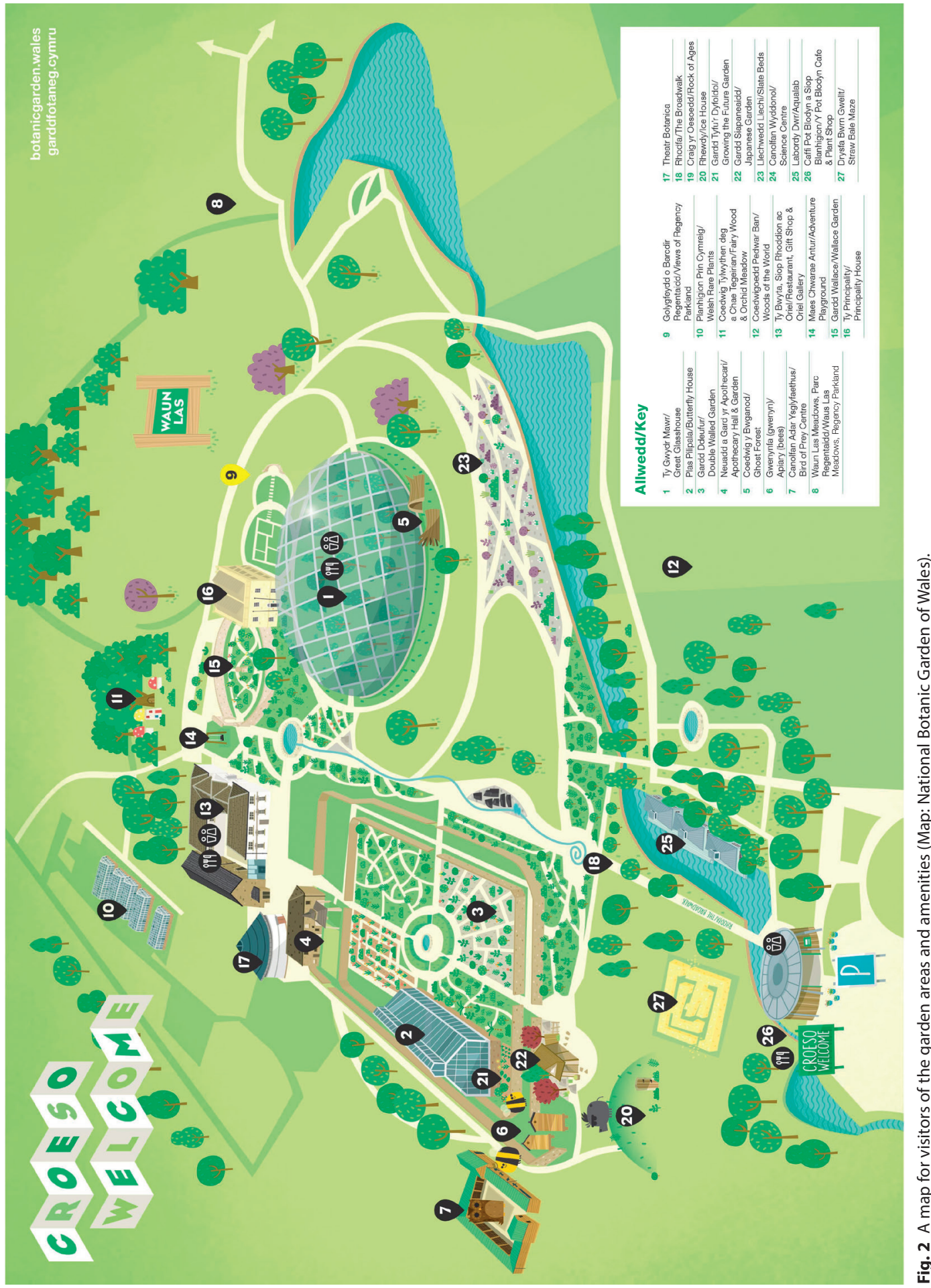


6-metre-deep ravine, and a porous substrate was installed. The Mediterranean climate zones' plant communities were selected as a theme to help communicate their ecological and conservation stories (Sclater \& Clarke, 2000). Despite covering only 2 per cent of the world's land surface, 20 per cent of plant diversity can be found in these regions (Jørgensen, 2009). In light of the featured habitats and plant communities' continued degradation, increasing encroachment by human activities and a changing climate, the Great Glasshouse will continue to play an important role in education and ex situ conservation for many years to come.

\section{Living collections}

During Prance's early involvement and Maunder's time as a consultant, the emphasis was on the development of plant collections for scientific research and conservation. Maunder suggested that a new botanic garden was an opportunity to develop collections which were 'unencumbered by old specimens of secondary scientific value' (Maunder, 1990a; 1990b). To help achieve this aim, Dr Quentin Kay was appointed as Botanical Coordinator in 1995. Kay, who had recently retired from Swansea University, was a highly regarded field botanist with a comprehensive knowledge of the Welsh flora. As Botanical Coordinator, he was tasked with developing a strategy for all plant collections and made recommendations regarding acquisitions, required taxa and the budgets necessary for such work (Kay, 1995). The mantle for developing the living collections was later passed to the first staff members for the Horticulture Department: Ivor Stokes, Head of Horticulture, and Wolfgang Bopp, Curator. With the mission in mind, Kay's guidance and ample ambition, the first plants started to arrive in 1997. Goodwill from the horticulture community was apparent and

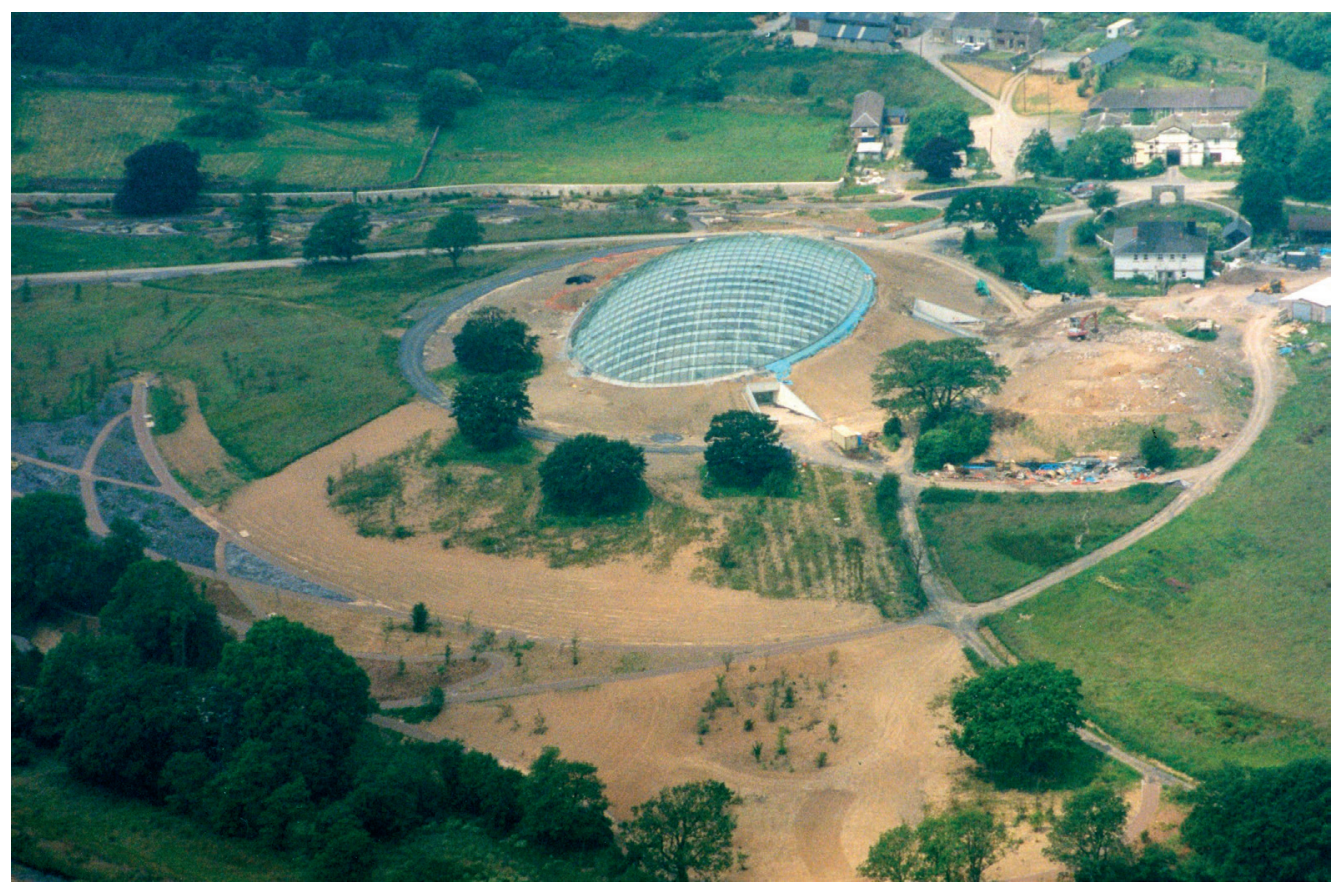

Fig. 3 The Great Glasshouse during the latter stages of construction in 1999 (Photo: National Botanic Garden of Wales). 


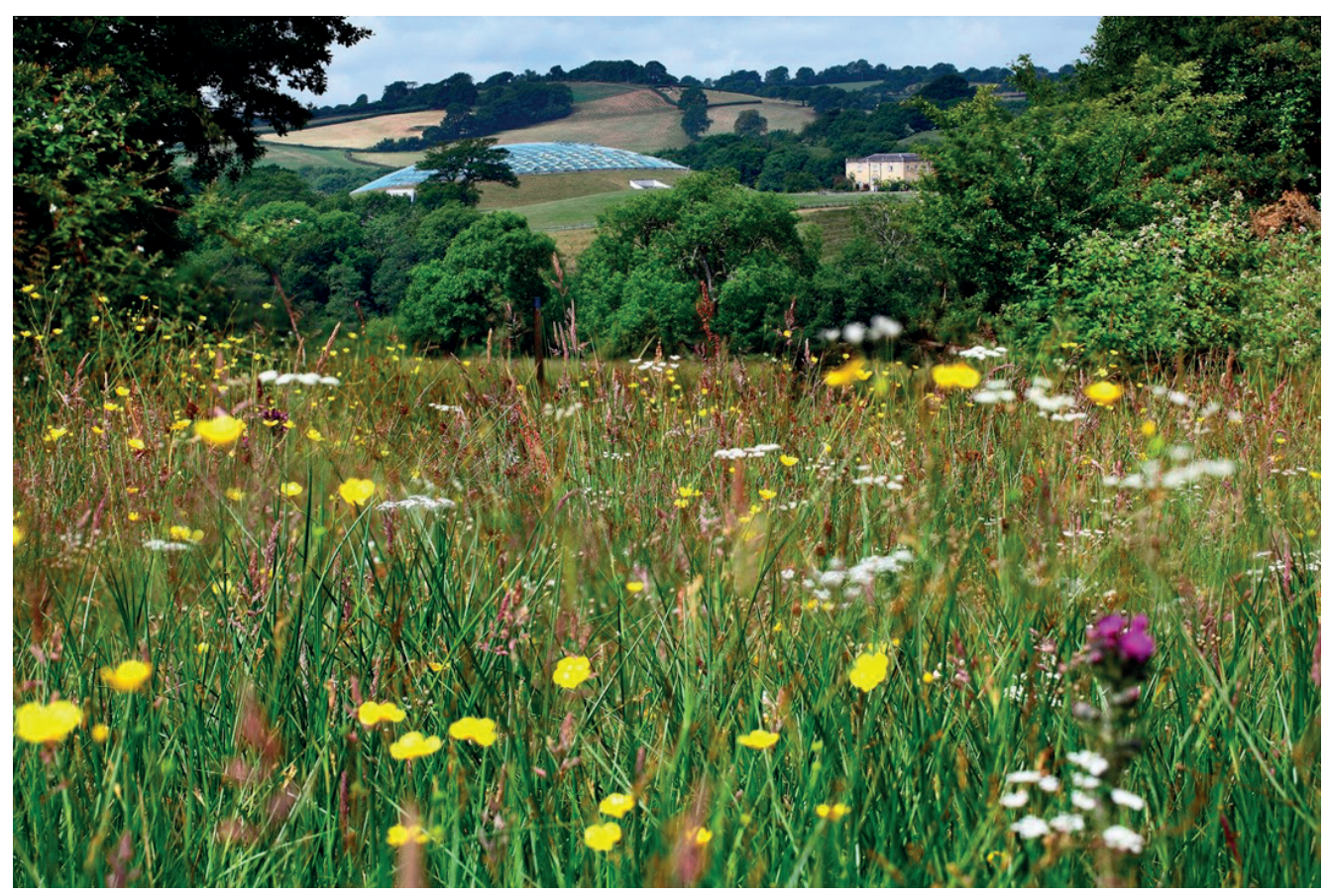

Fig. 4 Views of the Great Glasshouse from Waun Las National Nature Reserve (Photo: National Botanic Garden of Wales).

could be illustrated by a series of generous donations. Specimens from the Royal Botanic Garden Edinburgh (RBGE) expeditions to Taiwan (1993 ETE), China (1993 KEG) and Chile (1996 ICE), for example, were notable early additions.

By 2003, however, the development of the living collections was being hindered by the challenging financial circumstances that the Botanic Garden was enduring. Priorities changed due to necessity, staff numbers were substantially reduced and plant acquisitions were few. Those who remained were reluctant to access plant materials as they were not confident that the plants would be able to receive the care they required. In 2004, only 29 accessions were created. When the Botanic Garden began to stabilise, the number of accessions did inevitably rise. During the period between 2005 and 2016, another interesting trend was recorded: the number of cultivars purchased increased substantially but there was little change in the number of wild-origin plants acquired. The reasons for this are many and perhaps common. A leaner budget, for example, resulted in a reduced capacity for developing partnerships and conducting fieldwork. Likewise, generating higher visitor numbers and income required more ornamental planting, capacity was directed towards development of the visitor experience and accessing plant material from commercial nurseries was time-efficient. In recent years, much effort has been made to improve the utility and value of the collections. Greater financial sustainability since 2016 has facilitated a renewed focus on the mission and intentions of the Botanic Garden's originators. Between 2016 and 2019 the percentage of plant acquisitions of wild origin increased by 51 per cent. This was aided by the development of new partnerships, fieldwork and generous donations from other botanic gardens once more. 




Fig. 5 Cotoneaster cambricus, a critically endangered species which is endemic to the Great Orme in North Wales and supported by ex situ collections held by the National Botanic Garden of Wales, Treborth Botanic Garden and FossilPlants (Photo: National Botanic Garden of Wales).

In an age of increasing biodiversity loss and over 20 per cent of plant taxa facing extinction, the future development of the living collections must be focused and purposeful (Royal Botanic Gardens, Kew, 2016). Great progress has been made in conserving and celebrating Wales' plant diversity since the Botanic Garden opened, and the flora of Wales will continue to be a priority. Recent studies and the cultivation of Red List vascular species like Cotoneaster cambricus (Fig. 5), Sorbus leyana and Drymocallis rupestris have helped to protect vulnerable populations of rarities (Dines, 2008). Seed banking facilities have been developed parallel to an expanded cultivation programme to help safeguard the flora for future generations. Wales aims to be a 'globally responsible' nation, and such ambitions are enshrined not only in policy but in legislation (The National Archives, 2020). As importers and consumers of, and, historically, profiteers from the world's genetic resources, it is crucial that we acknowledge our privileged position. Therefore, we are committed to supporting plant conservation globally to help redress the inequalities of our history, providing resources and contributing to Wales' global aims (Fig. 6). To achieve this, the Botanic Garden will:

1. develop ex situ plant collections of value and utility for conservation practitioners, scientific researchers and educators

2. support capacity building and the development of local plant conservation initiatives. 


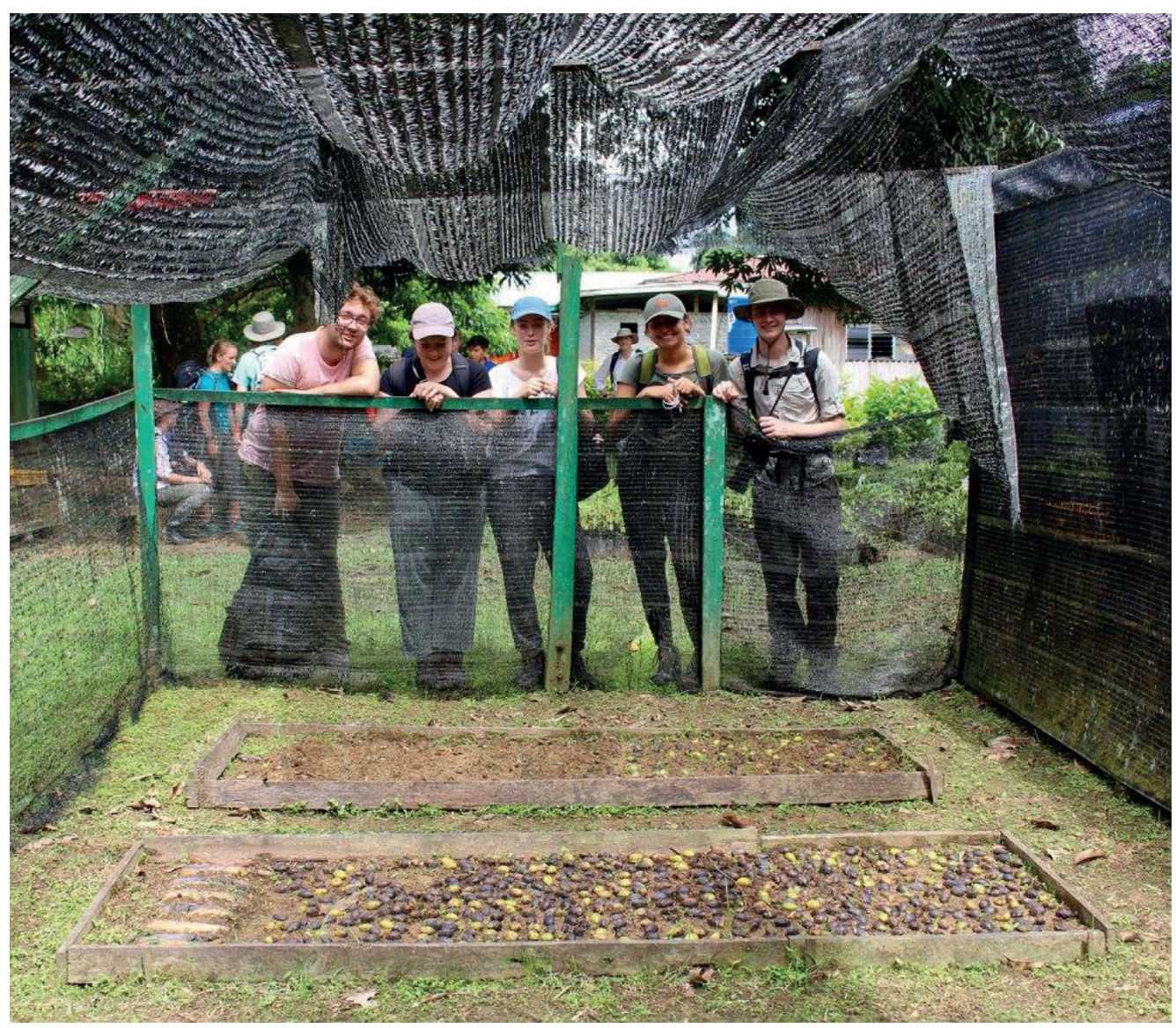

Fig. 6 Students from Aberystwyth University at a conservation tree nursery in Borneo, learning about conservation initiatives supported by the National Botanic Garden of Wales (Photo: Dr Natasha de Vere).

A recent joint expedition to Vietnam (2019) is an example of such an approach. Permitted and sustainable seed collections were made for ex situ cultivation at four UK botanic gardens, and new links were established with colleagues at the Institute for Ecological and Biological Resources in Hanoi. The next steps are further documentation and assessments, capacity building and the development of local ex situ sites for ecological restoration initiatives. Together with RBGE, Cambridge University Botanic Garden, $\mathrm{BGCl}$, and Fauna and Flora International, we aim to continue with this work.

\section{Science}

The rare opportunity to create a new science programme for a national botanic garden attracted many of Wales' leading botanists to the project. The aim was to develop a programme fit for the 21st century, free of historical collections and capable of meeting current and future challenges. The early involvement of Kay and John Savidge of the Botanical Society of the British Isles, and later Barry Thomas of the National Museum Wales, helped shape the important role the Botanic Garden would play in safeguarding the Welsh flora. The establishment of the Science Development Advisory Committee and the 
involvement of the influential Professor Dianne Edwards of Cardiff University helped to embed further new approaches to the interpretation, teaching and study of botany. Prof. Edwards supported horticulturists to create themed gardens and interpret complex topics such as plant genetics and systematics (Edwards \& Spears, 2011) (Fig. 7). The ambition was to create a new relationship between science and society, remove barriers to academia, and create resources relevant to the lives, cultures and communities of Wales and beyond.

Under the leadership of Dr Natasha de Vere, Head of Conservation and Research since 2008, the Botanic Garden has come to exemplify this approach to accessible and innovative science. With an expanding scientific team, now consisting of 18 staff members and having supervised 22 research interns and $12 \mathrm{PhD}$ researchers, the Science Centre is now a prominent hub for biodiversity research in Wales (de Vere, 2020). Notable projects have brought the Botanic Garden's science to international attention. Wales became the first nation in the world to DNA barcode all of its native flowering plants (de Vere et al., 2012). Such research and resources have fostered further benefits for people and biodiversity in Wales. Scientific studies conducted at the Botanic Garden now inform guidance on the best plants for pollinators by season (Fig. 8), the foraging preferences of honeybees and annual seed mixes to support biodiversity in domestic gardens and smallholdings. Exemplary practices are demonstrated on Waun Las NNR, and a Plants for Pollinators Assurance Scheme has been launched in collaboration with 23 nurseries.

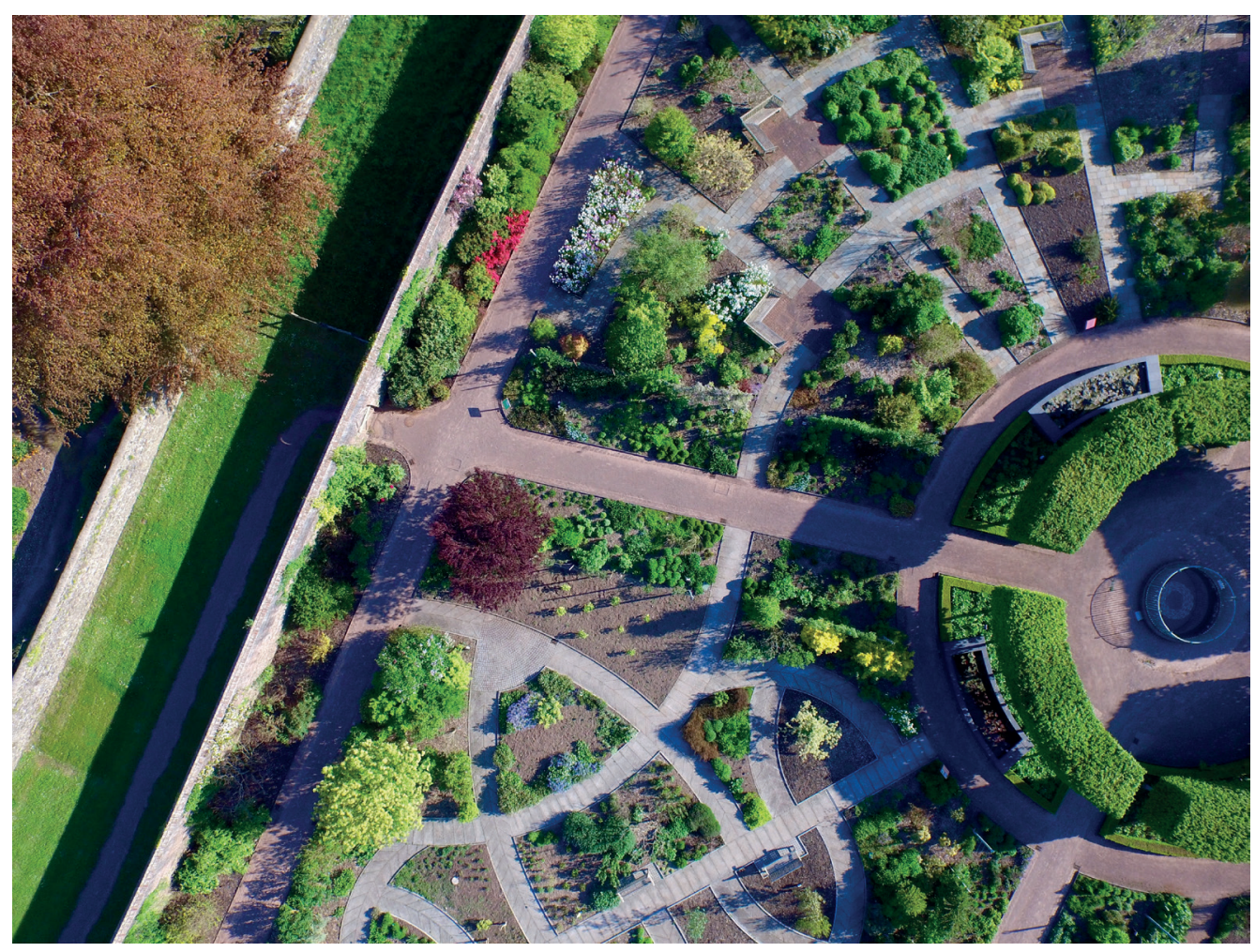

Fig. 7 An overview of the Double Walled Garden's systematic plant collection, which is arranged according to the Angiosperm Phylogeny Group III classification system (Photo: National Botanic Garden of Wales). 


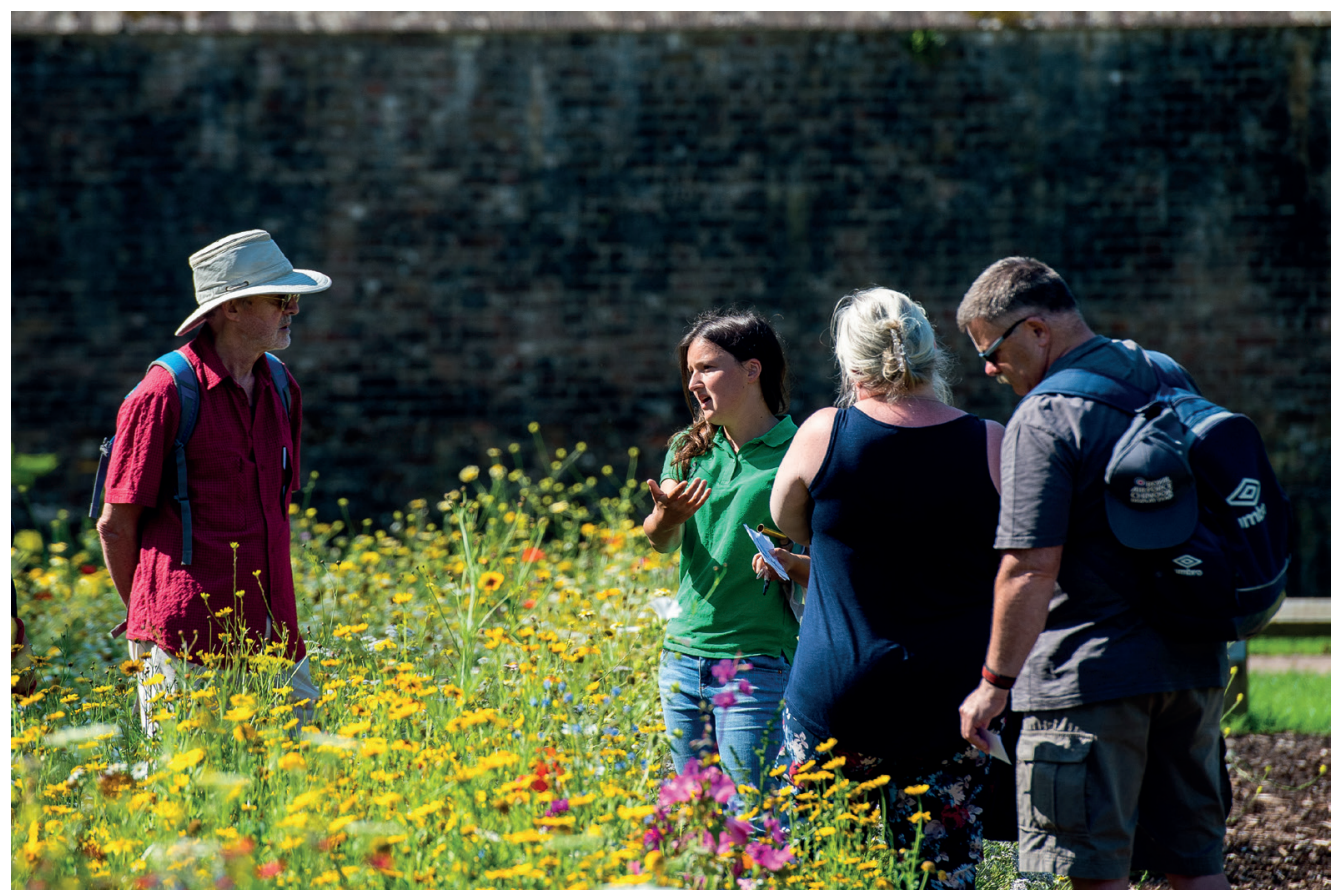

Fig. $8 \mathrm{PhD}$ student Lucy Witter explaining her studies designing pollinator-friendly seed mixes for horticulture (Photo: National Botanic Garden of Wales).

To better engage with society at large and fulfil our role as a national institution, it is imperative that the Botanic Garden is able to communicate its messages beyond its own gates. Growing the Future and Biophilic Wales are two projects through which the Botanic Garden reaches communities across the nation. Growing the Future aims to promote horticulture for health, wellbeing and as an industry. This is achieved through six hub sites, public events, courses and media. Biophilic Wales works with partners such as the Swansea Bay University Health Board to deliver inspiring public spaces, develop resilient grassland ecosystems and engage people in plant conservation activities. Both projects help the Botanic Garden to influence, educate and develop the interrelationship between people and plants. The Botanic Garden's journey has been beautifully circular. When Prance, Rothschild and Wilkins met on that platform in Port Talbot in 1989, it may have been hard to imagine the reach and impact their germinating idea would later have on that same community.

\section{Conclusion}

For many botanic gardens, museums and public institutions, establishing roots in a community takes time to achieve. These are long-term projects which need to be nurtured in their early years and decades to help them grow. In comparison to our counterparts in Scotland, England and Ireland, the National Botanic Garden of Wales will remain perennially young. However, the achievements and milestones of recent years are signs of a maturing and capable organisation, well positioned to meet many of the greatest challenges of our time. The growth we are experiencing now would not have been possible without the hard work 
and dedicated efforts of many before us. As we look to the future, we aim to continue growing, use our assets and strengths to the best of our ability, and play a vital role in defence of global plant diversity on behalf of the people of Wales.

\section{References}

BONVOISIN, S. (2016). Parkland Conservation Management Plan. Nicholas Pearson Partnership LLP, Tiverton.

BROADMEADOW, M., RAY, D. \& SAMUEL, C. (2005). Climate change and the future for broadleaved tree species in Britain. Forestry: An International Journal of Forest Research, 78(2): 145-161, doi: 10.1093/forestry/cpi014.

CLIMATE-DATA (2020). Climate data for the National Botanic Garden of Wales. Available online: https://en.climate-data.org/europe/unitedkingdom/wales/carmarthen-6749 (accessed August 2020).

COMPANIES HOUSE (1994). Certification of incorporation of a private limited company, Middleton Botanic Garden. Companies House, Cardiff.

DE VERE, N. (2020). Strategic Plan for Science at the National Botanic Garden of Wales. National Botanic Garden of Wales, Llanarthne.

DE VERE, N.D., RICH, T.C., FORD, C.R., TRINDER, S.A., LONG, C., MOORE, C.W., SATTERTHWAITE, D., DAVIES, H., ALLAINGUILLAUME, J., RONCA, S., TATARINOVA, T., GARBETT, H., WALKER, K. \& WILKINSON, M.J. (2012). DNA barcoding the native flowering plants and conifers of Wales. PLoS ONE, 7(6), doi: 10.1371/journal.pone.0037945.

DINES, T. (2008). A vascular plant red data list for Wales - Rhestr o blanhigion fasgwlaidd data coch ar gyfer Cymru. Plantlife International, Salisbury.
EDWARDS, D. \& SPEARS, P. (2011). Flowering plant families at the National Botanic Garden of Wales: based on the classification system of the Angiosperm Phylogeny Group. First Publishing, London.

GRATZFELD, J. (ED.) (2016). From Idea to Realisation - BGCl's Manual on Planning, Developing and Managing Botanic Gardens. Botanic Gardens Conservation International, Richmond.

JØRGENSEN, S.E. (2009). Ecosystem Ecology. Elsevier B.V., Amsterdam.

KAY, Q.O.N. (1995). Plant collections at the National Botanic Garden of Wales; overall objectives (report). National Botanic Garden of Wales, Llanarthne.

MAUNDER, M. (1990a). Notes on botanic garden function for the Middleton Steering Group (report). Royal Botanic Gardens, Kew.

MAUNDER, M. (1990b). The National Botanic Garden for Wales: A botanic garden for the 21st century (report). Royal Botanic Gardens, Kew.

PRANCE, G.T. (1989a). Letter to E.L. Rothschild, 26 October.

PRANCE, G.T. (1989b). Letter to W.P. Wilkins, 28 October.

ROYAL BOTANIC GARDENS, KEW (2016). The State of the World's Plants 2016 (report). Royal Botanic Gardens, Kew.

SCLATER, A. \& CLARKE, G. (2000). The National Botanic Garden of Wales. London: HarperCollins Illustrated.

THE NATIONAL ARCHIVES (2020). Well-being of Future Generations (Wales) Act 2015. The National Assembly for Wales (now Senedd Cymru - Welsh Parliament).

WILKINS, W.P. (1998). Letter to C. Stirton, 19 May. WYSE JACKSON, P.S. (1999). Experimentation on a large scale - an analysis of the holdings and resources of botanic gardens. Botanic Gardens Conservation News, 3(3): 27-30. 